\title{
Dukungan Irlandia Terhadap Upaya Perdamaian di Palestina
}

\author{
Rostamaji Korniawan \\ Kajian Wilayah Eropa, Pascasarjana Universitas Indonesia \\ Rostamaji_k@yahoo.com
}

\section{Abstract}

This article aimed at reviewing Ireland's support for reconciliation of Palestine. Conflict of Palestine and Israel, in essence, has characteristics that are almost equal to conflict took place in Ireland. Therefore, the reconciliation process of Irish conflict underlay Ireland's support towards Palestinian. This article is written using literature review. The finding of this article is that Ireland using soft diplomacy in helping Palestinians, namely political support through the UN as well as statements of support from Irish politicians, economic pressure (through boycott), financial aid, and accommodating Palestinian refugees. But at the same time, Ireland continues to do economic cooperation with Israel.

Keywords: Irish Aid, Palestine-Israel conflict, economic relation Ireland-Israel, economic boycott.

\section{Abstrak}

Artikel ini bertujuan mengkaji bantuan Irlandia terhadap upaya perdamaian di Palestina. Konflik Palestina-Israel pada dasarnya memiliki karakteristik yang hampir sama dengan konflik yang terjadi di Irlandia. Karena itu, proses perdamaian konflik di Irlandia menjadi landasan bagi Irlandia dalam mendukung upaya mewujudkan perdamaian di Palestina. Artikel ini ditulis dengan menggunakan kajian literatur. Temuan artikel ini adalah bahwa Irlandia dalam membantu Palestina lebih banyak melakukan soft diplomacy, yaitu upaya dukungan politik di PBB maupun pernyataan dukungan para politisi, upaya tekanan ekonomi (melalui aksi boikot), bantuan dana, serta menampung 
para pengungsi Palestina. Namun di saat yang sama, Irlandia tetap melakukan kerjasama ekonomi dengan Israel.

Kata kunci: Irlandia, konflik Palestina-Israel, hubungan ekonomi Irlandia-Israel, boikot ekonomi.

\section{Pendahuluan}

Konflik di jalur Gaza belum menunjukkan tanda-tanda penyelesaian secara tuntas. Palestina sampai saat ini masih memperjuangkan kedaulatannya untuk mengubah tatanan ekonomi, sosial, maupun pemerintahan yang ada di wilayahnya. Perjuangan Palestina dalam membebaskan diri dari intimidasi Israel yang masih berlangsung saat ini setidaknya mendapatkan dukungan dari berbagai negara, termasuk negara-negara di kawasan Eropa.

Irlandia sebagai salah satu negara anggota Uni Eropa merupakan salah satu negara yang turut mendukung Palestina mewujudkan impiannya menjadi satu negara yang berdaulat dan bebas dari segala macam bentuk penindasan maupun peperangan. Dukungan Irlandia terhadap Palestina bukan merupakan sebuah bentuk dukungan yang baru dilakukan. Dukungan Irlandia terhadap kebebasan Palestina secara historis telah dilakukan sejak beberapa tahun yang lalu. Hal ini dapat dilihat dari dukungan pemerintah Irlandia maupun masyarakat melalui bisnis yang dijalankan di kawasan Timur Tengah. Meskipun Irlandia tidak secara langsung memiliki jaringan bisnis di Palestina, Irlandia tidak melakukan intervensi secara langsung terhadap konflik yang terjadi antara Palestina dan Israel.

Pandangan Irlandia terhadap Palestina pada dasarnya hampir sama dengan pandangan Uni Eropa yang juga mendukung penyelesaian damai antara Palestina dan Israel. Keterlibatan Uni Eropa dalam proses perdamaian Palestina dan Israel menunjukkan komitmen Uni Eropa untuk menjadikan Uni Eropa sebagai asosiasi negara-negara Eropa yang dapat menyelesaikan masalah ekonomi, masalah sosial, maupun masalah keamanan di dalam lingkungan masyarakat internasional.

Dukungan Irlandia terhadap Palestina untuk menjadi sebuah negara yang berdaulat menjadi perhatian khusus di dalam artikel ini. Irlandia memang tidak memiliki hubungan sejarah, geopolitik, maupun geoekonomi 
dengan Palestina secara khusus sebelumnya. Tetapi negara ini tampaknya memiliki ketertarikan tersendiri dalam menyelesaikan konflik di Palestina dan Israel. Oleh sebab itu, artikel ini mencoba mengkaji mengapa Irlandia mendukung perjuangan Palestina dalam mewujudkan sebuh impian negara yang berdaulat. Kajian ini akan menggunakan pendekatan literatur.

Konflik di Palestina belum menunjukkan tanda-tanda penyelesaian secara tuntas. Palestina sampai saat ini masih memperjuangkan kedaulatannya untuk mengubah tatanan ekonomi, sosial, maupun pemerintahan yang ada di wilayahnya. Perjuangan Palestina dalam membebaskan diri dari intimidasi Israel yang masih berlangsung saat ini setidaknya mendapatkan dukungan dari berbagai negara, termasuk negara-negara di kawasan Eropa.

Irlandia sebagai salah satu negara anggota Uni Eropa merupakan salah satu negara yang turut mendukung Palestina mewujudkan impiannya menjadi satu negara yang berdaulat dan bebas dari segala macam bentuk penindasan maupun peperangan. Dukungan Irlandia tidak terjadi baru-baru ini saja, melainkan sejak tahun 1950-an dimana Irlandia telah menjadikan solusi konflik Palestina-Israel dan penanganan terhadap masalah pengungsi Palestina sebagai salah satu prioritas kebijakan luar negerinya di Timur Tengah. Israel didirikan tahun 1948, namun baru tahun 1963 Irlandia memberikan pengakuannya dan Kedutaan Besar Irlandia di Tel Aviv baru berdiri tahun 1996.

Sejak beberapa tahun terakhir, suara politisi maupun aktivis perdamaian Irlandia semakin kuat dan bahkan mereka menyerukan boikot ekonomi terhadap Israel. Meskipun beberapa aksi boikot telah berhasil dilakukan, sejauh ini Irlandia tidak melakukan intervensi secara langsung terhadap konflik yang terjadi antara Palestina dan Israel.

Pandangan Irlandia terhadap Palestina pada dasarnya hampir sama dengan pandangan Uni Eropa yang juga mendukung penyelesaian damai antara Palestina dan Israel. Keterlibatan Uni Eropa dalam proses perdamaian Palestina dan Israel menunjukkan komitmen Uni Eropa untuk menjadikan Uni Eropa sebagai asosiasi negara-negara Eropa yang dapat menyelesaikan masalah ekonomi, masalah sosial, maupun masalah keamanan di dalam lingkungan masyarakat internasional. 
Dukungan Irlandia terhadap Palestina untuk menjadi sebuah negara yang berdaulat menjadi perhatian khusus di dalam artikel ini. Irlandia memang tidak memiliki hubungan sejarah maupun geopolitik dengan Palestina secara khusus. Tetapi negara ini tampaknya memiliki ketertarikan tersendiri dalam menyelesaikan konflik di Palestina dan Israel. Oleh sebab itu, artikel ini mencoba mengkaji mengapa Irlandia mendukung perjuangan Palestina dalam mewujudkan sebuah impian negara yang berdaulat. Kajian ini akan menggunakan pendekatan literatur.

\section{Hubungan Ekonomi Irlandia, Israel, dan Palestina}

Dalam konteks hubungan ekonomi, meskipun mendukung kemerdekaan Palestina, Irlandia tetap menjalin kerjasama dengan Israel. Pada 20 November 1995, kedua negara telah menandatangani perjanjian Double Tax Agreement yang memberikan sebuah kepastian agar tidak terjadi pengenaan pajak berganda di kedua negara akibat transaksi yang dilakukan oleh wajib pajak atau konsumen tersebut.

Menurut data 2011, nilai ekspor Irlandia ke Israel sebesar 995 miliar US Dollar, sedangkan nilai impor dari Israel senilai 74 miliar US Dollar. Barang yang terbanyak diekspor Irlandia ke Israel adalah mesin dan peralatan elektronik, bahan persiapan pangan, obat-obatan, dan mesin optik. Sebaliknya, Irlandia mengimpor bahan kimia, perlatan medis, peralatan pengukuran, dan mesinmesin. ${ }^{1}$ Pada tahun 2014, media Irlandia memberitakan bahwa selama tiga tahun sebelumnya, pemerintah telah mengekspor perlengkapan militer ke Israel senilai 6,4 juta Euro. Berita ini segera ditanggapi dengan kritik keras dari partai oposisi dan kelompok-kelompok pendukung Palestina. ${ }^{2}$

Sebaliknya, kondisi perekonomian di Palestina semakin hari semakin memburuk akibat tekanan Israel. Wilayah ini sebenarnya memiliki sumber kekayaan alam yang signifikan, perkebunan maupun pertanian berkembang dengan baik. Palestina memiliki kesempatan untuk meningkatkan

1 Israel Economic Department Fact Sheet. 2011. Melalui <http://www.export.gov.il/files/ economy/factsheet11/ireland.pdf $>$ [11/6/2017]

2 Irishexaminer.com. 2014. "State approved $€ 6.4 \mathrm{~m}$ in Israel arms exports". Melalui <http://www.irishexaminer.com/ireland/state-approved-euro64m-in-israel-armsexports-283664.html $>$ [11/6/2017] 
perekonomiannya dengan memperdagangkan hasil produksi perkebunan dan pertaniannya. Namun, blokade dan embargo yang dilakukan Israel terhadap distribusi perdagangan dan investasi di Palestina membuat kekayaan alam tersebut tidak bisa termaksimalkan.

Menurut laporan lembaga PBB, United Nations Conference on Trade and Development (UNCTAD) pada tahun 2015, jika saja wilayah-wilayah Palestina tidak diduduki Israel, kondisi ekonomi Palestina akan dua kali lipat lebih baik daripada saat ini. Israel telah melakukan pembatasan pergerakan orang dan barang, penghancuran secara sistematis pada basis-basis produksi, dan aneksasi lahan dan air milik warga Palestina, sehingga kegiatan ekonomi terhambat. Blokade yang terjadi membuat warga Palestina bergantung pada Israel dalam pemenuhan kebutuhan. Warga Palestina harus mengimpor barang kebutuhannya sebanyak 55\% dari Israel, sementara ekspor Palestina ke Israel hanya $3 \%$ dari total perdagangan Israel. ${ }^{3}$

Seiring dengan waktu, konflik Palestina-Israel semakin memanas dan menghasilkan hubungan yang semakin tidak seimbang antara keduanya. Isolasi dan embargo yang dilakukan Israel terhadap Palestina menutup jalan perdagangan dan membuat kehidupan masyarakat di Palestina pun menjadi serba sulit. Kondisi ini mendorong Irlandia memberikan bantuan kepada Palestina, yang akhirnya membuka jalan perdagangan Irlandia-Palestina.

Menurut data dari United Nations Conference Trade and Development (UNCTAD), nilai perdagangan antara Irlandia dengan Palestina meningkat cukup pesat meskipun peningkatan nilai perdagangan tersebut tidak sebanyak peningkatan nilai perdagangan antara Irlandia dengan negaranegara Eropa maupun Amerika Serikat. Pada tahun 2000, nilai eskpor Irlandia ke Palestina tercatat sebesar US\$229 ribu. Lima belas tahun kemudian, nilai ekspor tersebut mengalami peningkatan hingga mencapai US\$7.688 ribu.

Sedangkan untuk nilai impor Irlandia dari Palestina, tahun 2001 nilai impor Irlandia tercatat sebesar US\$47 ribu. Sedangkan di tahun 2014, nilai impor Irlandia dari Palestina hanya mencatat nilai sebesar US\$5 ribu. Sebuah kombinasi perdagangan yang tidak sempurna di mana nilai eskpor Irlandia

3 UNCTAD. 2016. "Developments in the economy of the Occupied Palestinian Territory". Melalui <http://unctad.org/en/PublicationsLibrary/app2016d1_en.pdf> [11/6/2017] 
ke Palestina yang lebih besar dibandingkan dengan nilai ekspor Palestina ke Irlandia. Ketidakseimbangan ini tidak serta merta menjadikan hubungan ekonomi, khususnya hubungan perdagangan Irlandia dengan Palestina menjadi landasan hubungan bilateral yang tidak seimbang.

Besarnya nilai ekspor Irlandia ke Palestina pada dasarnya merupakan bentuk bantuan Irlandia kepada Palestina yang mengalami kekurangan akibat infrastruktur yang terbatas, investasi yang kurang, pelayanan publik yang tidak memadai, pemerintahan sementara yang rapuh, dan dana yang terbatas. Irlandia ingin menghidupkan hubungan bilateral dengan Palestina, meskipun Palestina belum menjadi sebuah negara yang resmi diakui dunia.

Keprihatinan Irlandia terhadap rakyat Palestina juga ditunjukkan dalam bentuk dukungan bantuan pendanaan yang disalurkan melalui the United Nations Relief and Work Agency (UNRWA). Dukungan penyaluran dana bantuan Irlandia kepada Palestina melalui UNRWA diberikan kepada para pengungsi Palestina. Yang dibutuhkan para pengungsi tentunya sebuah kebutuhan primer yang sangat mendesak di samping program pendidikan yang juga perlu untuk diperhatikan. Dengan program bantuan pendidikan, pemerintah Irlandia meyakini bahwa para pengungsi Palestina yang mendapatkan bantuan pendidikan dan kesehatan mampu menjadi pionir bagi masyarakatnya untuk segera memperbaiki situasi yang terjadi di wilayah Palestina.

Tahun 2010, pemerintah Irlandia memberikan bantuan kepada pengungsi Palestina sebesar $€ 9,07$ juta $^{4}$. Tahun 2012 , bantuan tersebut telah meningkat hingga mencapai $€ 11,47$ juta $^{5}$. Namun di tahun 2015, bantuan pemerintah Irlandia kepada pengungsi Palestina melalui fasilitas bantuan yang dilakukan oleh the United Nations Relief and Work Agency (UNRWA) hanya sebesar

$4 \quad$ Department of Foreign Affairs and Trade. 2010. "Irish Aid Annual Report: Aid Works, Delivering on Results.". Melalui<https://www.irishaid.ie/media/irishaid/ allwebsitemedia/20newsandpublications/publicationpdfsenglish/irish-aidannual-report-2010-low-res.pdf $>[1 / 6 / 2017]$

5 Department of Foreign Affairs and Trade. 2012. "Irish Aid Annual Report: Reducing Hunger, Strengthening Resilience. Department of Foreign Affairs and Trade". Melalui <https://www.irishaid.ie/media/irishaid/ allwebsitemedia/20newsandpublications/publicationpdfsenglish/irish-aidannual-report-2012-high-res.pdf>[1/6/2017 
$€ 1,5$ juta $^{6}$. Semua bantuan ini akan menjadi momentum kehadiran Irlandia di tengah-tengah masyarakat Palestina. Tetapi, apakah semua masyarakat Palestina merasakan semua bantuan itu? Fakta masih memperlihatkan jumlah penduduk yang miskin masih sangat besar. Data statistik yang dikeluarkan oleh badan statistik yang dikelola oleh pemerintahan sementara Palestina di tahun 2011 memperlihat bahwa 25.8\% penduduk Palestina masih mengalami kemiskinan. Sebagian besar pendudukmiskinnya tersebar di daerah pedesaan, yaitu sebesar $26.1 \%{ }^{7}$.

Kondisi ekonomi di Palestina tentu berbeda dengan kondisi ekonomi di Israel. Dalam konteks hubungan ekonomi bilateral Irlandia dan Israel, Irlandia tidak memberikan bantuan kepada Israel, karena Israel merupakan negara kaya dengan income per capita-nya yang lebih baik dibandingkan dengan income per capita Palestina. Menurut data PBB, income per capita Israel di tahun 2014 tercatat sebesar $\$ 38.500$. Sedangkan income per capita Palestina di tahun yang sama hanya sebesar $\$ 2.810$.

Dengan income per capita yang sangat besar, Israel menjadi daya tarik tersendiri bagi negara-negara lain. Irlandia, khususnya, melihat bahwa Israel merupakan salah satu negara yang tepat untuk menanamkan investasinya. Meskipun investasi berkembang di Israel, industri yang berkembang di Israel tampaknya bukan merupakan industri-industri yang menarik, semenarik seperti industri-industri yang berkembang di negara-negara Eropa maupun Amerika Serikat. Namun hal ini tidak menyurutkan Irlandia untuk berinvestasi di sana.

Salah satu investasi yang dilakukan Irlandia di Israel adalah investasi industri yang bergerak di bidang pengolahan produk semen. Cement Roadstone Holdings (CRH) adalah perusahaan Irlandia yang menjadi investor di Israel. Perusahaan ini melakukan memiliki saham kepemilikan sebanyak 25\% di grup perusahaan Mashav. Sedangkan Mashav merupakan Holding

$6 \quad$ Department of Foreign Affairs and Trade. 2015. "Irish Aid Annual Report: The Year in Review. Department of Foreign Affairs and Trade". Melalui <https:// www.irishaid.ie/media/irishaid/allwebsitemedia/20newsandpublications/ annualreport2015/IA-Annual-Report-2015.pdf > [1/6/2017]

7 Palestinian Central Bureau of Statistics. 2016. "Palestine in Figures, 2015. State of Palestine. Melalui < http://www.pcbs.gov.ps/Downloads/book2188.pdf> $[1 / 6 / 2017]$ 
Company untuk perusahaan Nesher Cement (Ireland Palestine Solidarity Campaign, 2014).

Persoalan timbul saat diketahui Nesher Cement Company memiliki hubungan dengan pembangunan tembok perbatasan di Tepi Barat. Pembangunan tembok pembatas wilayah Israel-Palestina merupakan satu persoalan besar dalam konflik Palestina-Israel. Tembok ini telah memenjarakan warga Palestina sehingga banyak dari mereka yang terpisah dari lahan pertanian atau dari desa tetangga. Tak heran bila banyak kecaman yang disampaikan komunitas internasional terhadap pembangunan tembok ini. Irlandia merupakan salah satu negara yang menolak pembangunan tembok ini meskipun di saat yang sama perusahaan Irlandia, $\mathrm{CRH}$, memiliki hubungan secara tidak langsung dengan Nesher Cement Company, yang berperan dalam pembangunannya.

Dengan demikian, meskipun Irlandia menjalin kerjasama ekonomi dengan Israel, Irlandia bersama-sama dengan Uni Eropa tetap menyuarakan pembelaannya terhadap Palestina.

\section{Resolusi Konflik Irlandia Sebagai Landasan}

Irlandia adalah sebuah pulau di Eropa, tepatnya di pesisir barat benua Eropa. Pulau ini terbagi menjadi 32 county (provinsi), dimana 26 county di Irlandia selatan kini telah menjadi sebuah negara berdaulat bernama Republik Irlandia dengan ibu kota Dublin. Sementara itu, 6 county yang lain tergabung dalam negara Irlandia selatan (dengan ibu kota Belfast) yang menjadi bagian dari Kerajaan Inggris.

Komitmen Irlandia dalam mendukung perjuangan Palestina untuk mendapatkan haknya sebagai negara berdaulat tidak terlepas dari pengalaman sejarah yang melekat di dalam kehidupan masyarakat Irlandia. Perseteruan penduduk Irlandia, khususnya penduduk yang ada wilayah utara Irlandia, merupakan konflik sektarian antara penganut Kristen Protestan dengan penganut Katolik.

Konflik ini menyebabkan perpecahan wilayah kepulauan Irlandia di mana Irlandia Utara menjadi bagian wilayah yang berada di kekuasaan Inggris 
dan bagian lainnya menjadi sebuah negara yang berdiri secara independen dengan kekuasaan yang besar yang ada di tangan rakyatnya, yaitu Republik Irlandia.

Konflik sektarian penduduk Irlandia merupakan akumulasi dari sejarah konflik yang terjadi di Irlandia. Irlandia merupakan wilayah yang dulunya merupakan wilayah kolonial Inggris yang kemudian menuntut upaya kemerdekaan dari pemerintahan kolonial Inggris. Namun ada sebagian penduduk Irlandia menolak rencana pemisahan diri dari Inggris. Faktor-faktor yang berperan dalam perbedaan pendapat antarpenduduk Irlandia ini antara lain perbedaan agama, perbedaan pandangan politik praktis, serta perbedaan kondisi ekonomi dan sosial.

Konflik bermula sejak gelombang kedatangan kaum imigran Inggris ke pulau Irlandia pada tahun 1609. Imigran Inggris memeluk agama Kristen Protestan sementara mayoritas warga Irlandia beragama Kristen Katolik. Kaum Kristen Protestan kemudian mendominasi Irlandia dan terjadilah berbagai bentuk diskriminasi. Pada tahun 1912, Inggris secara resmi menjadikan pulau Irlandia sebagai bagian dari wilayahnya. Sejak itulah, muncul 2 kelompok besar di Irlandia: kelompok loyalis dan unionis (mayoritas Protestan) yang pro-Inggris serta golongan nasionalis (mayoritasnya Katolik) yang menginginkan Irlandia merdeka. Pada 29 September 1937 akhirnya ditandatangani kesepakatan antara Inggris dan para pemimpin Irlandia selatan yang mengakui kemerdekaan Irlandia selatan. Namun karena adanya Perang Dunia II, baru pada tahun 1949 Republik Irlandia secara resmi mengumumkan kemerdekaannya. Sementara itu, bagian Irlandia yang masih menjadi bagian dari Inggris hingga kini masih terus berkonflik.

Konflik Irlandia pada dasarnya merupakan konflik sipil yang terjadi karena perbedaan pandangan keyakinan. Konflik ini melahirkan intimidasi dan kekerasan yang pada akhirnya membentuk The Irish Republican Army (IRA) pada 1916 sebagai bentuk perlawanan militer penduduk Irlandia (yang beragama Protestan) terhadap diskriminasi dan kekerasan yang mereka rasakan dari kelompok Kristen Katolik.

Pemberontakan IRA menjadi indikasi bahwa pengaruh dari kekuasaan (power) kolonialisme Inggris mengubah polarisasi pemikiran sebagian 
penduduk Irlandia untuk memusuhi saudaranya sendiri. Dengan politik kekuasaan pula, Irlandia menjadi wilayah yang memiliki dua persepsi yang berbeda, meskipun mereka pada dasarnya memiliki garis keturunan yang sama. Apabila dibandingkan dengan konflik Palestina-Israel, konflik Irlandia ini tentu sedikit berbeda. Meskipun demikian, baik konflik di Irlandia maupun konflik di Palestina-Israel, pengertian konflik pada hakikatnya telah menjadi bagian permasalahan sosial yang sudah dibakukan.

Di dalam teori demokrasi consociational, khususnya kaum poststrukturalist, konflik dipandang sebagai bagian dari proses demokrasi yang berkembang. Dengan timbulnya konflik di tengah masyarakat, demokrasi akan semakin menghasilkan pandangan yang beragam sebagai konsekuensi dari kebebasan yang diberikan masyarakatnya ${ }^{8}$. Itu artinya, konflik yang terjadi di Irlandia pada dasarnya juga merupakan proses demokrasi dari sebuah negara dengan keberagaman pandangan penduduknya.

Konflik panjang Irlandia ini akhirnya sedikit mereda di mana kaum nasionalis dengan kaum Unionist bersedia melakukan gencatan senjata di tahun 1994. Namun, dalam proses perdamaian yang sedang berlangsung, pelanggaran kesepakatan untuk tidak melakukan penyerangan maupun tindakan kekerasan masih juga terjadi. Di tahun 2012 setelah sepuluh tahun berhentinya konflik sektarian di Irlandia Utara, konflik sosial kembali muncul. Tetapi, semua permasalahan ini tidak menutup jalan bagi kedua pihak untuk menyelesaikan permasalahan di dalam satu kesepakatan. Namun, mulai dari Belfast Agreement sampai dengan St. Adrews Agreement, perselisihan dan kegagalan dalam menemukan titik kesepahaman masih juga saja terjadi. Jalan damai konflik Irlandia memang tidak mungkin membentuk sebuah masyarakat Irlandia yang damai dan ideal, karena sikap masyarakat terhadap adanya perbedaan maupun skeptisisme terhadap hasil kesepakatan pun masih terlihat di dalam masyarakat ${ }^{9}$. Generasi muda sebagai generasi yang seharusnya dapat menghapus memori buruk dari sejarah konflik Irlandia tampaknya juga mengalami sindrom yang sama di mana perbedaan status

8 Dixon, P. 2011. "Is Consociational Theory the Answer to Global Conflict? From the Netherlands to Northern Ireland and Iraq". Political Studies Review. Vol. 9: 309_ 322.

9 Shirlow, P. and Coulter, C. 2014. "Northern Ireland: 20 Years After the Cease-Fires". Studies in Conflict and Terrorism. Vol. 37: 713-719. 
sosial, politik, budaya, maupun demografi masih dipersoalkan di tengahtengah masyarakat Irlandia, khususnya masyarakat Irlandia Utara.

\section{Dukungan Irlandia Terhadap Perjuangan Palestina 1959-2016}

Perjuangan Irlandia membentuk sebuah negara yang berdiri sendiri seperti yang telah diuraikan secara singkat sebelumnya memiliki makna tersendiri bagi masyarakat Irlandia, khususnya warga negara Republik Irlandia. Perjuangan ini tampaknya mempengaruhi pandangan mereka terhadap perjuangan Palestina. Dukungan terhadap Palestina telah ditunjukkan Irlandia sejak masa pemerintahan Eamonn de Valera (1959-1973), tepatnya pada saat Frank Aiken menjabat sebagai Menteri Luar Negeri (1957-1969). Selama masa jabatannya, Frank Aiken menyalurkan bantuan kepada Palestina melalui UNRWA. ${ }^{10}$

Partai oposisi terkemuka Irlandia, yaitu partai nasionalis Sinn Féin, hingga kini konsisten dalam mendukung Palestina. Salah satu politisi Sinn Féin, Mary Lou McDonald, pernah mempertanyakan sikap pemerintah Irlandia terhadap kelanjutan perjuangan dalam rapat dengar pendapat yang dihadiri oleh salah satu prewakilan pemerintah, yaitu Joan Burton selaku Tánaiste and Minister for Social Protection pada waktu. Menurut Joan, pemerintah tidak bermaksud menghalangi perjuangan masyarakat Irlandia untuk turut mendukung secara langsung perjuangan Palestina. Namun, pemerintah tidak menginginkan ada masyarakat Irlandia yang terluka akibat dukungan langsung itu.

Irlandia pernah terjun langsung dalam mendukung upaya perdamaian, melalui pengiriman pasukan perdamaian 1978-2000 ke Lebanon. Akibatnya, Irlandia harus kehilangan sejumlah prajurit dalam konflik bersenjata pihak proPalestina melawan Israel. Namun konflik ini pula yang akhirnya mendorong pemerintah Irlandia mendukung Palestina menjadi sebuah negara berdaulat. Irlandia menjadi negara pertama di Uni Eropa yang mendukung kemerdekaan Palestina.

Dari beberapa Presiden Irlandia yang terpilih yang mayoritasnya berasal dari Partai Fianna Fáil, mereka banyak yang mendukung Palestina

10 Miller, R. 2010. "Why the Irish Support Palestine". Melalui <http://foreignpolicy. com/2010/06/23/why-the-irish-support-palestine-2/> [1/6/2017] 
menjadi sebuah negara. Pada masa pemerintahan Mary McAleese yang juga merupakan anggota Fianna Fáil, dia juga mendukung perjuangan Palestina. Tahun 2004 menjadi momen yang sangat penting dalam masa pemerintahan Mary McAleese karena pada tahun ini dia dihadapkan pada petisi yang ditandatangani oleh 12.000 anggota masyarakat dan 52 anggota parlemen, termasuk anggota parlemen Eropa, senator, dan politisi independen. Petisi berisi seruan boycott terhadap produk-produk yang berasal dari Israel.

Sementara itu, Irlandia Utara yang merupakan bagian dari kekuasaan Inggris juga menunjukkan dukungan kepada perjuangan Palestina, walaupun ada sebagian masyarakat Irlandia Utara yang cenderung berpihak kepada Israel.

\section{Bantuan Irlandia terhadap Palestina di Tengah Skeptisisme}

Keberpihakan Irlandia sebagai sebuah negara Eropa (Barat) kepada Palestina memunculkan dilema. Sebagaimana diketahui, Barat sangat berperan dalam terjadinya konflik Palestina-Israel. Israel didirikan tahun 1948 setelah adanya Resolusi PBB no. 18 tanggal 29 November 1947 yang menyerahkan sebagian wilayah Palestina untuk menjadi wilayah Israel. Jauh sebelumnya, pada tanggal 2 November 1917, Menteri Luar Negeri Inggris Lord Balfour mengirimkan sebuah surat kepada Walter Rothschild, pemimpin komunitas Yahudi Inggris kala itu, yang berisi kesediaan pemerintah Inggris untuk menciptakan sebuah negara Yahudi di wilayah Palestina.

Selain itu, dalam sejarah perjuangan negara-negara Arab, dominasi dan intervensi Amerika Serikat terhadap kedaulatan negara-negara Timur Tengah dan keberpihakan Amerika Serikat terhadap Israel menjadi ancaman keamanan negara-negara Arab ${ }^{11}$. Amerika Serikat memiliki pengaruh yang besar dalam penyelesaian konflik Palestina-Israel. Namun, penyelesaian konflik yang diupayakan oleh Amerika Serikat tersebut belum memberikan hasil yang maksimal. Perjanjian Camp David menjadi perjanjian inisiasi untuk memperbaiki kondisi Timur Tengah pada tahun 1978 setelah negaranegara Timur Tengah mengalami kerusakan akibat perang Yom Kippur.

11 Machmudi, Y., Hidayat, R., dan Agustina, E. 2016. Sejarah Timur Tengah Kontemporer: Kepemimpinan di Arab Saudi dan Libya. Jakarta: Universitas Indonesia Press. (53) 
Amerika Serikat yang diwakilkan oleh Presiden Jimmy Carter membuat strategi agar negara-negara Arab dapat menyelesaikan konflik secara damai dengan Israel. Dalam perjalanan perdamaian tersebut, Amerika Serikat akhirnya mengundang perwakilan negara-negara Arab yang pada waktu itu diwakilkan oleh Presiden Mesir, Anwar Sadat, dan Perdana Menteri Israel, Menachem Begin, untuk membuat kesepakatan damai. Namun perjanjian ini tidak disetujui oleh masyarakat Arab pada umumnya. Salah satu negara yang secara frontal menentang kesepakatan ini antara lain Libya. Dalam pandangan pemerintahan Muammar Khadafi, perjanjian Israel dan Mesir merupakan perjanjian yang mencederai persatuan negara-negara Arab. ${ }^{12}$

Sara Roy, peneliti di Harvard University yang banyak memfokuskan penelitiannya di Jalur Gaza menggambarkan kehidupan ekonomi Palestina yang porak poranda dan mengakibatkan kemiskinan penduduknya. Menurut Roy, kemiskinan ini bukan disebabkan faktor alam melainkan karena adanya tindakan-tindakan Israel akibat pandangan negatif ataupun kecurigaan yang berlebihan. Israel sangat mencurigai banyak kemungkinan faktor-faktor yang dapat mengancam gangguan keamanan di wilayah mereka. ${ }^{13}$

Di sisi lain, di tengah warga Palestina juga terjadi konflik, yaitu antara kelompok Hamas dan Fatah. Di dalam masyarakat Israel, konflik internal pun terjadi, yaitu pertentangan di antara dua kelompok Yahudi. Sebagian besar dari mereka pro-Israel dan memandang bahwa berdirinya Israel adalah bagian dari janji Tuhan kepada kaum Yahudi. Mereka ini umumnya berpaham Zionisme. Kaum Zionis merupakan perpecahan dari komunitas Yahudi yang memiliki pandangan yang jauh liberal dan radikal. Kaum Zionis inilah yang memiliki pandangan untuk menciptakan Israel sebagai satu negara khusus umat Yahudi. Namun sebagian umat Yahudi yang menjalankan keyakinannya secara murni menentang hal ini karena menurut mereka, penjajahan bukan ajaran Yahudi. Mereka menilai bahwa kaum Zionis telah melakukan tindakan

12 Machmudi, Y., Hidayat, R., dan Agustina, E. 2016. Sejarah Timur Tengah Kontemporer: Kepemimpinan di Arab Saudi dan Libya. Jakarta: Universitas Indonesia Press. (121-153)

13 Priyatna, H. 2009. Kebiadaban Zionisme Israel: Kesaksian Orang-Orang Yahudi. Bandung: PT Mizan Pustaka. (204-215) 
kekerasan yang sebenarnya telah keluar dari konteks agama Yahudi yang murni.

Perilaku kaum Zionis terhadap warga Palestina tidak berbeda dengan perilaku para penjajah yang telah menduduki wilayah Palestina sebelum berdirinya Israel. Inggris menjadi salah satu negara Eropa yang menduduki dataran Palestina pada masa itu. Tindakan kaum Zionis ini mengingatkan perjuangan Irlandia melawan pendudukan Inggris. Namun, perjuangan kemerdekaan Irlandia, khususnya Irlandia Utara, tidak sepenuhnya didukung oleh warga Irlandia. Sebagian penduduk Irlandia memilih bergabung dengan pemerintahan kolonial Inggris dan inilah yang akhirnya menjadi sumber perpecahan di dalam masyarakat Irlandia.

Relasi Barat-Arab yang tidak harmonis dari sisi bahwa negara-negara Barat banyak mendukung Israel, memunculkan sikap skeptis di pihak Palestina atas bantuan Irlandia dalam memperjuangkan perdamaian di Palestina. Apalagi, Irlandia sendiri secara historis memiliki hubungan dekat dengan Amerika Serikat maupun Inggris, negara yang berperan penting dalam terbentuknya Israel.

Namun di tengah skeptisisme itu, Irlandia tetap melanjutkan upaya bantuannya. Terlebih lagi, Irlandia yang penduduknya mayoritas beragama Katolik memiliki cara pandang yang khas terhadap Palestina. Mereka menuruti cara pandang Paus sebagai pimpinan tertinggi umat Katolik yang secara jelas mendukung perdamaian di Palestina. Dukungan Irlandia terhadap Palestina mengacu kepada keyakinan Katolik untuk memberikan rasa aman dan keadilan bagi siapa pun.

Bentuk-bentuk bantuan yang diberikan Irlandia kepada Palestina antara lain sebagai berikut.

a. Menerima kehadiran pengungsi Palestina. Tidak hanya menerima kehadiran pengungsi Palestina, Irlandia juga memberikan kesempatan kepada pengungsi untuk menyampaikan aspirasinya di tengah-tengah masyarakat Irlandia. Penyaluran kebebasan suara pengungsi Palestina diakomodasi melalui Kampanye Solidaritas Irlandia-Palestina(Ireland Palestine Solidarity Campaign - IPSC). 
Beberapa kali komunitas ini mengadakan forum pertemuan dan menyuarakan aspirasi mereka, yang didukung oleh pengungsi dari Palestina dan masyarakat Irlandia.

b. Melakukan aksi boikot terhadap produk-produk yang diimpor dari Israel. Melalui aksi ini, masyarakat Irlandia ingin menyampaikan kepada publik ketidaksetujuan mereka atas perlakuan Israel kepada bangsa Palestina. Masyarakat Irlandia bergabung dalam aksi Boikot, Divestasi, dan Sanksi (BDS) yang juga didukung oleh warga negara-negara Eropa lainnya. Dalam sidang Parlemen Irlandia, Mei 2016, Menteri Luar Negeri Charles Flanagan menyatakan bahwa "meskipun pemerintah secara resmi tidak mendukung kebijakan ini, tetapi gerakan BDS memiliki "pandangan politik yang sah" dan pemerintah tidak setuju pada upaya pembunuhan karakter pada tokoh-tokoh yang mendukung BDS."14 Media Israel, Maariv, pada tahun 2014 melaporkan bahwa aksi BDS global telah menyebabkan kerugian 100 juta shekel bagi Israel. Gerakan BDS juga memberikan kerugian kepada perusahaan yang terlibat dalam aksi penjajahan Israel, seperti Veolia, yang kehilangan kontrak senilai lebih dari 20 miliar USD di beberapa negara, termasuk Irlandia.

Perusahaan Amdocs milik Israel juga pernah diboikot di Irlandia. Pada tahun 2010, sejumlah politisi Irlandia, antara lain Proinsias De Rossa MEP, Chris Andrews TD dan Cllr. Richard Boyd Barrett, menggalang petisi yang ditujukan kepada Eircom, operator telekomunikasi di Irlandia. Isi petisi itu menyerukan agar Eircom tidak menandatangani proposal kerjasama dari sebuah konsorsium yang di dalamnya beranggotakan Amdocs. Alasannya, Amdocs adalah penyokong kebijakan perang Israel yang telah menewaskan ribuan orang di Gaza. ${ }^{15}$

14 Oireachtas. 2016. "Undocumented Irish in the USA". Melalui<http:// oireachtasdebates.oireachtas.ie/debates\%20authoring/debateswebpack.nsf/ takes/ dail2016052600033?opendocument> [1/6/2017]

15 Detik.com. 2010 "Di Indonesia Boleh, Amdocs Dijegal di Irlandia". Melalui <http://inet. detik.com/telecommunication/d-1396184/di-indonesia-boleh-amdocs-dijegal-diirlandia> [1/6/2017] 
c. Irlandia memberikan dukungan politik kepada perjuangan Palestina. Di PBB, Irlandia mendukung resolusi-resolusi pro-Palestina. Antara lain, pada September 2015, Irlandia mendukung resolusi yang membolehkan bendera Palestina (sebagai negara observer, belum menjadi anggota PBB) dikibarkan di markas PBB.

Pada tahun 2014, pasca serangan Israel ke Gaza, pimpinan partai politik Sinn Féin, Gerry Adams, berkunjung ke jalur Gaza. Sebagai partai nasionalis yang mendukung kemerdekaan Irlandia dari kolonialisme Inggris, kunjungan Gerry Adams yang difasilitasi oleh UNRWA merupakan kunjungan yang ingin menyampaikan solidaritas perjuangan. Kunjungan ini sempat dihalangi Israel walaupun pada akhirnya, Gerry Adams berhasil menemui sebagian penduduk Palestina untuk melihat kondisi mereka secara langsung.

\section{Tawaran Resolusi Konflik Palestina-Israel dengan Berkaca Pada Pengalaman Irlandia}

Dalam proses perdamaian yang terjadi di Irlandia ada hal-hal yang bisa ditawarkan kepada Palestina dan hal ini menjadi salah satu alasan di balik intensitas upaya beberapa politisi Irlandia, terutama partai nasionalis, untuk membantu upaya perdamaian di Palestina. Dalam proses perdamaian yang dilakukan pimpinan partai politik di Irlandia, kesatuan pandangan dengan membagi kekuasaan (power sharing) di dalam pemerintahan menjadi satu cara yang strategis untuk menghindari konflik yang dapat berkembang.

Dari catatan sejarah berdirinya Republik Irlandia, pembagian kekuasaan pemerintahan Irlandia Utara, dan hubungan antara Irlandia Utara, Inggris, maupun Republik Irlandia, semua itu diinisiasi melalui Perjanjian Belfast (Belfast Agreement) yang dilakukan pada tahun 1998. Perjanjian tersebut dibuat untuk menjaga hubungan baik antara Irlandia Utara, Republik Irlandia, dan Inggris agar konflik yang berlangsung sangat lama di Irlandia dapat diredam. Melalui perjanjian ini pula, para pimpinan partai politik yang ada di wilayah Irlandia melakukan koordinasi dengan membentuk pola pembagian kekuasaan. Power sharing pemerintahan yang diwujudkan pemerintahan 
Irlandia Utara menjadi salah satu wujud keberhasilan pimpinan partai politik yang ada di Irlandia.

Gerry Adams dan Martin McGuinness adalah pemimpin partai politik Sinn Féin yang berhasil menyakinkan semangat nasionalisnya dalam mendukung Perjanjian Belfast untuk mewujudkan perdamaian di Irlandia.

Secara garis besar, Perjanjian Belfast menyetujui diplomasi hubungan baik antara Irlandia Utara, Republik Irlandia, dan Inggris. Pertama, perjanjian ini menyepakati pembentukan sistem dan status pemerintahan Irlandia Utara terhadap Inggris. Kedua, perjanjian ini juga menyepakati tindak lanjut hubungan antara Irlandia Utara dengan Republik Irlandia. Ketiga, perjanjian ini juga menyepakati kelanjutan hubungan antara Republik Irlandia dan Inggris. Perjanjian Belfast kemudian menjadi menjadi dasar kelanjutan proses damai dari konflik yang terjadi di Irlandia.

Peran partai politik dalam proses damai di Irlandia telah menyatukan kepentingan yang berbeda. Empat partai politik yang dominan pada waktu itu, yaitu Democratic Unionist Party (DUP), Sinn Féin, Ulster Unionist Party (UUP), dan Social Democratic and Labor Party (SDLP), melakuan power sharing, meskipun DUP dan Sinn Féin menjadi partai yang memegang kendali dalam proses pembagian kekuasaan tersebut. ${ }^{16}$

Meskipun tak dapat dipungkiri, pasca perdamaian, Irlandia belum sepenuhnya dapat dikatakan bebas dari konflik. Sewaktu-waktu, perselisihan mungkin akan timbul kembali. Hal ini disebabkan karena masih ada sikap perbedaan pandangan yang dimiliki warga Irlandia, terutama generasi muda yang tampaknya masih memiliki pandangan yang sama seperti generasi sebelumnya, yaitu perbedaan pandangan di antara dua penganut keyakinan yang berbeda.

Tawaran power sharing untuk diterapkan di wilayah konflik Palestina-Israel bisa jadi merupakan kemungkinan solusi bagi konflik ini. Biar bagaimanapun, konflik tidak akan pernah usai bila masing-masing pihak berkeras pada posisinya masing-masing. Tentu saja, ada perbedaan karakteristik politik antara Irlandia dengan Palestina dan Israel. Namun tak bisa dipungkiri bahwa

16 McMahon, E. 2015.“Does the Peace Process in Northern Ireland Offer a Model for Resolving Historic Conflict?. American Foreign Policy Interests. Vol. 37: 209-213 
konflik itu terjadi di pusat kulminasi pertemuan tiga agama, yaitu Yahudi, Islam, dan Kristen.

Konflik sektarian yang terjadi di Irlandia, yaitu antara Katolik dan Kristen, pada hakikatnya berakar dari sejarah perkembangan agama yang sama. Agama Katolik dan agama Kristen memiliki karakteristik keyakinan yang tidak jauh berbeda. Demikian pula dengan agama Islam dan agama Yahudi yang memiliki sejarah yang sambung-menyambung (sama-sama dihantarkan oleh keturunan Nabi Ibrahim), meskipun keduanya bukan merupakan keyakinan yang dapat disamakan. Dengan demikian, meskipun kecil, ada peluang bahwa pengalaman Irlandia mengatasi konflik sektarian dapat diadopsi.

\section{Kesimpulan}

Irlandia adalah bagian dari negara Eropa yang bersatu dengan negaranegara Eropa lainnya karena ikatan common history yang mereka miliki. Namun sejarah yang dimiliki Irlandia dalam menghadapi kolonialisme Inggris dan konflik sektarian telah mendorong warga dan politisinya untuk mendukung perjuangan Palestina melawan penindasan Israel. Dalam upaya ini, Irlandia lebih banyak melakukan soft diplomacy, yaitu upaya dukungan politik di PBB maupun pernyataan dukungan para politisi, upaya tekanan ekonomi (melalui aksi boikot), bantuan dana, serta menampung para pengungsi Palestina.

Di sisi lain, Irlandia tetap mempertahankan hubungan baiknya dengan Israel, antara lain terlihat dari kerjasama ekonomi Irlandia-Israel yang tetap stabil. 